\title{
Properties of NAD+- and NADP+-dependent malic enzymes of Rhizobium (Sinorhizobium) meliloti and differential expression of their genes in nitrogen-fixing bacteroids
}

\author{
Brian T. Driscoll $†$ and Turlough M. Finan \\ Author for correspondence: Turlough M. Finan. Tel: +1 9055259140 ext. 22932. Fax: +19055226066. \\ e-mail: finan@McMaster.CA
}

Department of Biology, McMaster University, 1280 Main St W, Hamilton, Ontario, Canada L8S 4K1
The wild-type NAD+-dependent malic enzyme (dme) gene of Rhizobium (now Sinorhizobium) meliloti was cloned and localized to a $3.1 \mathrm{~kb}$ region isolated on the cosmid pTH69. This cosmid complemented the symbiotic nitrogen fixation (Fix ${ }^{-}$) phenotype of $R$. meliloti dme mutants. The dme gene was mapped by conjugation to between the cys-11 and leu-53 markers on the $R$. meliloti chromosome. $\beta$-Galactosidase activities measured in bacterial strains carrying either dme-lacZ or tme-lacz gene fusions (the tme gene encodes NADP+. dependent malic enzyme) indicated that the dme gene was expressed constitutively in free-living cells and in $\mathbf{N}_{\mathbf{2}}$-fixing bacteroids whereas expression of the tme gene was repressed in bacteroids. The $R$. meliloti dme gene product (DME) was overexpressed in and partially purified from Escherichia coli. The properties of this enzyme, together with those of the NADP*-dependent malic enzyme (TME) partially purified from $R$. meliloti dme mutants, were determined. Acetyl-CoA inhibited DME but not TME activity. This result supports the hypothesis that DME, together with pyruvate dehydrogenase, forms a pathway in which malate is converted to acetyl-CoA.

Keywords: Rhizobium (Sinorhizobium) meliloti, malic enzyme, malate dehydrogenase, pyruvate

\section{INTRODUCTION}

Rhizobia induce root nodules on leguminous plants. There is much evidence that the nitrogen-fixing bacteria (called bacteroids) within nodules are supplied with $\mathrm{C}_{4}$ dicarboxylic acids as their primary energy source. For example, transport (dct) mutants from several Rhizobium species which fail to transport $\mathrm{C}_{4}$-dicarboxylic acid as bacteroids also fail to fix nitrogen ( $\mathrm{Fix}^{-}$ phenotype) (Ronson et al., 1981; Finan et al., 1983; Arwas et al., 1985; Bolton et al., 1986; Engelke et al., 1987; Yarosh et al., 1989; Van Slooten et al., 1992).

†Present address: Department of Natural Resource Sciences, McGill University, Macdonald Campus, 21111 Lakeshore, Ste-Anne-de-Bellevue, Québec, Canada H9X 3 V9.

Abbreviations: DME, NAD+-dependent malic enzyme (EC 1.1.1.39); $L D H$, lactate dehydrogenase; $M D H$, malate dehydrogenase; OAA, oxaloacetic acid; PCK, phosphoenolpyruvate carboxykinase; $\mathrm{PDH}$, pyruvate dehydrogenase; PEP, phosphoenolpyruvate; POD, pyruvate orthophosphate dikinase; TCA, tricarboxylic acid; TME, NADP ${ }^{+}$-dependent malic enzyme (EC 1.1.1.40).
Metabolism of $\mathrm{C}_{4}$-dicarboxylic acids, such as malate, via the tricarboxylic acid (TCA) cycle (Stoval \& Cole, 1978; Streeter, 1991), requires synthesis of equimolar amounts of oxaloacetate (OAA) and acetyl-CoA. OAA is the product of the oxidation of malate via malate dehydrogenase (MDH), and acetyl-CoA is formed from pyruvate via pyruvate dehydrogenase $(\mathrm{PDH})$.

In Rhizobium (now Sinorhizobium) meliloti bacteroids the first step in the synthesis of acetyl-CoA from $\mathrm{C}_{4}{ }^{-}$ dicarboxylic acids appears to take place via the $\mathrm{NAD}^{+}$dependent malic enzyme. Malic enzymes convert malate to pyruvate plus $\mathrm{CO}_{2}$, and simultaneously reduce either $\mathrm{NAD}^{+}$or $\mathrm{NADP}^{+}$to $\mathrm{NADH}$ or NADPH, respectively. The alfalfa symbiont, $R$. meliloti produces two distinct malic enzymes. The $\mathrm{NAD}^{+}$-dependent malic enzyme, (designated DME for diphosphopyridine-nucleotidedependent malic enzyme) shows maximal activity with $\mathrm{NAD}^{+}$as cofactor and this enzyme has reduced $(>20 \%)$ activity when $\mathrm{NADP}^{+}$is used as cofactor. $R$. meliloti dme mutants, lacking DME fail to fix nitrogen in alfalfa nodules (Driscoll \& Finan, 1993). The second 
Table 1. Bacterial strains and plasmids

\begin{tabular}{|c|c|c|}
\hline $\begin{array}{l}\text { Strain or } \\
\text { plasmid }\end{array}$ & Relevant characteristics* & Source \\
\hline \multicolumn{3}{|l|}{ R. meliloti } \\
\hline $\mathrm{Rm} 1021$ & SU47, str-21 & Driscoll \& Finan (1993) \\
\hline $\mathrm{Rm} 5000$ & SU47, rif-5 & Finan et al. (1988) \\
\hline RmG212 & Rm1021, $\mathrm{Lac}^{-}$ & Jane Glazebrook, MIT, USA \\
\hline $\mathrm{RmG} 243$ & Rm1021, pckA3: :Tn3HoHo1Sp pod-1 & Driscoll \& Finan (1993) \\
\hline RmG450 & RmG243, dme-1: : Tn5 & Driscoll \& Finan (1993) \\
\hline $\mathrm{RmG} 443$ & $\mathrm{RmG} 243, d m e-2:: \operatorname{Tn} 5$ & Driscoll \& Finan (1993) \\
\hline RmG456 & $\operatorname{Rm} 1021, d m e-1:: \operatorname{Tn} 5$ & Driscoll \& Finan (1993) \\
\hline RmG454 & $\operatorname{Rm} 1021, d m e-2:: \operatorname{Tn} 5$ & Driscoll \& Finan (1993) \\
\hline RmG492 & $\operatorname{Rm} 5000, d m e-2:: \operatorname{Tn} 5$ & Driscoll \& Finan (1993) \\
\hline $\mathrm{RmG} 494$ & $\operatorname{Rm} 5000, d m e-1:: \operatorname{Tn} 5$ & Driscoll \& Finan (1993) \\
\hline RmG699 & $\operatorname{Rm} 1021, \Omega 5285:: \operatorname{Tn} 5-233$ & This study \\
\hline RmG700 & $\operatorname{Rm} 1021, \Omega 5286:: \operatorname{Tn} 5-233$ & This study \\
\hline $\mathrm{RmH} 182$ & RmG212 (pTH226) & This study \\
\hline RmH201 & RmG212 (pTH233) & This study \\
\hline $\mathrm{RmH} 239$ & $\mathrm{RmG} 212, d m e-7:: \operatorname{Tn} 5-\mathrm{B} 20$ & This study \\
\hline $\mathrm{RmH} 240$ & $\mathrm{RmG} 212$ (pTH69) & This study \\
\hline $\mathrm{RmH} 242$ & RmG212 (pTH241) & This study \\
\hline \multicolumn{3}{|l|}{ E. coli } \\
\hline EJ1321 & galK2 pck dme tme, Str ${ }^{\mathrm{r}}$ & Hansen \& Juni (1975) \\
\hline G312 & MT607 $\Omega 5: ~: \operatorname{Tn} 5-B 20$ & Driscoll \& Finan (1993) \\
\hline \multicolumn{3}{|l|}{ Plasmids } \\
\hline pLAFR1 & Broad-host-range cosmid vector, $\mathrm{Tc}^{\mathrm{r}}$ & Friedman et al. (1982) \\
\hline pRmT100 & pLAFR 1 clone, carries the $n t r A$ and tme genes & Finan et al. (1988) \\
\hline pTH69 & pLAFR 1 clone, complements $d m e$ mutants & This study \\
\hline pTH226 & pTH69, dme-7: :Tn5-B20 & This study \\
\hline pTH233 & pRmT100, tme-7: :Tn5-B20 & Driscoll \& Finan (1996) \\
\hline pTH241 & pTH69, dme-8: :Tn5-B20 & This study \\
\hline pRK7813 & Broad-host-range cloning vector, $\mathrm{Tc}^{\mathrm{r}}$ & Jones \& Gutterson (1978) \\
\hline pTH109 & pRK7813, 3.1 kb HindIII fragment of pTH69 & This study \\
\hline pTH111 & pRK7813, 3.1 kb HindIII fragment of pTH69 & This study \\
\hline pTH113 & pRK7813, 8.5 kb EcoRI fragment of pTH69 & This study \\
\hline pTH114 & pRK7813, 8.5 kb EcoRI fragment of pTH69 & This study \\
\hline pTH138 & pUC119, $3 \cdot 1 \mathrm{~kb}$ HindIII fragment of pTH69 & This study \\
\hline pTH139 & pUC119, 3.1 kb HindIII fragment of pTH69 & This study \\
\hline
\end{tabular}

*Sp, spectinomycin; Str, streptomycin; Rif, rifampin; Tc, tetracycline.

malic enzyme (TME: triphosphopyridine-nucleotidedependent malic enzyme), only shows activity with $\mathrm{NADP}^{+}$as cofactor. This enzyme is not required for symbiotic $\mathrm{N}_{2}$-fixation as tme mutants induce wildtype $\mathrm{N}_{2}$-fixing root nodules (Driscoll \& Finan, 1996).

As part of a continuing study of malic enzymes and nodule metabolism we have isolated and characterized the $d m e$ gene, and have partially characterized the DME and TME enzymes from $R$. meliloti. Our findings, in particular the inhibition of DME, but not TME, by acetyl-CoA, indicate that the end-product of the metabolic pathway to which DME belongs is acetyl-CoA. We therefore propose that DME is required for symbiotic $\mathrm{N}_{2}$-fixation because it is part of the metabolic pathway which converts $\mathrm{C}_{4}$-dicarboxylic acids to acetyl-CoA in bacteroids.

\section{METHODS}

Bacterial strains, media and genetic techniques. $R$. meliloti and Escherichia coli strains and plasmids used in this study are listed in Table 1. Bacterial media and culture conditions, plant growth, shoot dry weight determinations and acetylene reduction assays were done as previously decribed (Yarosh et al., 1989).

Phage $\phi \mathrm{M} 12$ transduction, conjugal mating, $\mathrm{Tn} 5$ and Tn5-B20 mutagenesis, and recombination of markers into the $R$. meliloti genome were performed as previously described (Charles \& Finan, 1990; Driscoll \& Finan, 1996; Finan et al., 1988; Yarosh et al., 1989). The R. meliloti dme gene was isolated following transfer of the pLAFR1 library (Friedman et al., 1982) into the dme pck pod-1 strain RmG450. Complementing plasmids were selected on M9 minimal media containing succinate and tetracycline $\left(2 \mathrm{mg} \mathrm{m}^{-1}\right)$. 


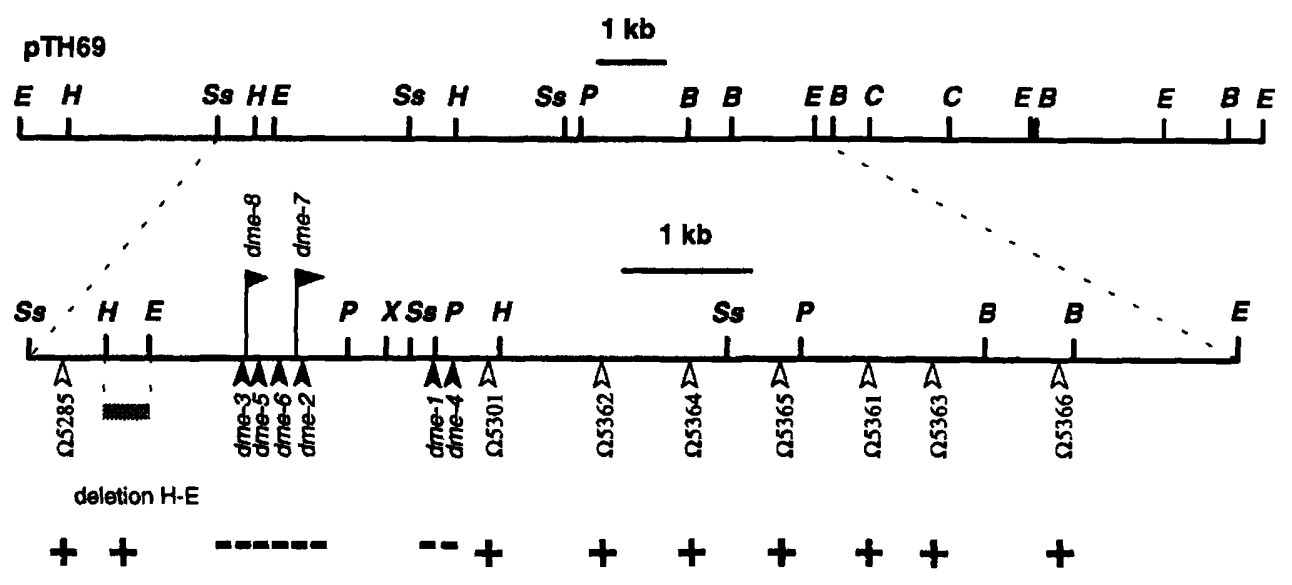

Fig. 1. Physical map of pTH69 and the dme gene region. H, Hindlll; B, BamHI; P, Pstl; Ss, Sstl; E, EcoRI; X, Xhol; C, Clal. Tn5 insertions within the dme gene are indicated by black arrowheads, Tn5 insertions outside the dme gene are indicated by white arrowheads (insertion $\Omega 5285$ is Tn5-233). The dme-7::Tn5-B20 and dme-8::Tn5-B20 insertions are indicated by black flags which point in the direction of transcription of the promoterless lac $Z$ gene. The $d m e-1, d m e-2$ and dme-3 Tn5 insertions were mapped by Southern hybridization employing pTH69 as probe. The grey bar represents a deletion of $0.4 \mathrm{~kb}$ between the indicated HindIII and EcoRI sites. The + and - signs indicate insertions which produce $\mathrm{Dme}^{+}$and $\mathrm{Dme}^{-}$phenotypes, respectively.

To map the dme gene we first employed a standard transduction procedure to isolate the Tn5-233 insertions $\Omega 5285$ and $\Omega 5286$ in strains RmG699 and RmG700 which are $100 \%$ and $30 \%$ linked, respectively, by co-transduction to dme (Charles \& Finan, 1990). The Tn5-mob insertions $\Omega 601, \Omega 602, \Omega 611$, $\Omega 612, \Omega 614, \Omega 615$ and $\Omega 637$ (Klein et al., 1992) were transduced into strains RmG699 and RmG700, and the mobilizing plasmid pGMI102 (Finan et al., 1988) was then transferred from $E$. coli into one of each of the above transductants. Each of the resulting strains carrying Tn $5-m o b$, Tn5-233 and pGMI102 was mated overnight with $\mathrm{Rm} 5000$. The mating mixtures, together with donor and recipient controls, were then plated on LB containing rifampicin, spectinomycin and gentamycin.

Plasmid DNA isolation, transformation, DNA restrictions, agarose gel electrophoresis and Southern hybridizations were done according to standard protocols (Sambrook et al., 1989). In plasmids pTH109, pTH113 and pTH139, the vector lac promoter is positioned to the left of the insert fragment (as depicted in Fig. 1). In plasmids pTH111, pTH114 and pTH138, the vector lac promoter is positioned to the right of the fragment (as depicted in Fig. 1).

Biochemical techniques. DME was isolated from $3 \mathrm{l}$ of $E$. coli EJ1321(pTH139) cells which were grown in LB medium (plus $50 \mathrm{mg} \mathrm{ml}^{-1}$ ampicillin) at $37^{\circ} \mathrm{C}$. Cells were centrifuged, resuspended in buffer 1 [20 mM Tris pH 8.4, $1 \mathrm{mM} \mathrm{MgCl}$, $10 \mathrm{mM} \mathrm{KCl}, 20 \%$ (v/v) glycerol, $10 \mathrm{mM} \beta$-mercaptoethanol] and disrupted by sonication. Following centrifugation, the protein extracts were concentrated by ultrafiltration using an Amicon stirred cell with a YM30 ( $M_{\mathrm{r}} 30000$ exclusion) membrane. The resulting protein solution was then washed by ultrafiltration with several volumes of degassed buffer 1 . Fractions containing the DME protein were isolated from this protein solution by DEAE-cellulose column chromatography as previously described (Driscoll \& Finan, 1993, 1996). TME was isolated from cell-free extracts of two different $d m e$ mutant strains. Following DEAE-cellulose chromatography (see Driscoll \& Finan, 1993), elution fractions between $230 \mathrm{ml}$ and $285 \mathrm{ml}$ for RmG492 protein and between $195 \mathrm{ml}$ and $250 \mathrm{ml}$ for $\mathrm{RmG} 494$ protein were pooled, concentrated and washed by ultrafiltration with several volumes of buffer 1 . Neither lactate dehydrogenase (LDH) nor pyruvate dehydrogenase activities were detected in the DME preparation.

Protein concentrations were determined using the BioRad protein assay dye and BSA (bovine serum albumin) as a standard. Malic enzyme specific activity $\left[\mathrm{nmol} \mathrm{min}^{-1}(\mathrm{mg}\right.$ protein $)^{-1}$ ] of extracts was determined from the rate of pyruvate formation (Driscoll \& Finan, 1993). The assay

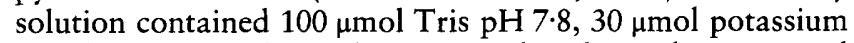
L-malate, $3 \mu \mathrm{mol} \mathrm{MnCl}, \quad 50 \mu \mathrm{mol} \mathrm{KCl}$ and $0.25 \mu \mathrm{mol}$ $\mathrm{NAD}(\mathrm{P})^{+}$in a final volume of $1 \mathrm{ml}$. For most assays, the malate solution was made by adjusting the $\mathrm{pH}$ of the malate (free acid) to 7.8 with $\mathrm{KOH}$ (potassium L-malate). To study the effects of monovalent cations (in the absence of excess potassium) the $\mathrm{pH}$ of the malate solution was adjusted to $7 \cdot 8$ with $\mathrm{NaOH}$ (sodium L-malate). For partially purified DME and TME preparations, malic enzyme activity was determined from the rate of reduction of $\mathrm{NAD}(\mathrm{P})^{+}$to $\mathrm{NAD}(\mathrm{P}) \mathrm{H}$, measured by absorption at $340 \mathrm{~nm}$ (Uvikon 930 spectrophotometer). When using $\mathrm{NAD}^{+}$reduction, the concentration of $\mathrm{NAD}^{+}$ used was increased from $0.25 \mathrm{mM}$ to $2.5 \mathrm{mM}$. Malate dehydrogenase activity was determined by the method of Englard \& Siegal (1969). $\beta$-Galactosidase activities (as Miller units or as specific activities [ $\mathrm{nmol} \mathrm{min}^{-1}(\mathrm{mg} \text { protein })^{-1}$ ] were determined by the method of Miller (1972), as previously described (Driscoll \& Finan, 1996).

SDS-polyacrylamide (10\% total acrylamide, $3.3 \%$ crosslinked) gel electrophoresis of proteins was done according to standard procedures (Sambrook et al., 1989), using broadrange molecular mass standards (Pharmacia). Enzyme kinetic data were analysed using the Biosoft Fig.P (version 6.0c) program.

\section{RESULTS}

\section{Isolation of a cosmid clone carrying the wild-type dme gene}

Mutants of R. meliloti which lack the enzyme phosphoenolpyruvate carboxykinase (PCK) grow poorly on minimal medium with succinate as carbon source (Finan 
et al., 1988). We have isolated suppressor mutations (e.g. pod-1) which allow $\mathrm{Pck}^{-}$mutants to grow like the wild-type on succinate minimal medium. The suppressor mutations result in increased pyruvate orthophosphate dikinase (POD) activity, which in turn allows enhanced production of phosphoenolpyruvate (PEP) from pyruvate (M. Østerås, B. T. Driscoll \& T.M. Finan, unpublished). Mutant strains which lack NAD ${ }^{+}$dependent malic enzyme activity $(d m e)$ grow like the wild-type on succinate (Driscoll \& Finan, 1993). However, when dme mutations are transferred into strains such as RmG243 that are $\mathrm{Pck}^{-}$and carry the pod-1 mutation, the resulting strains grow poorly on succinate minimal medium.

The $d m e$ structural gene was isolated by complementation of the succinate-growth phenotype of $d m e$ pckA pod-1 mutants (RmG450 and RmG443) with an $R$. meliloti clone bank. Two classes of complementing plasmids were identified by restriction enzyme analysis. As expected, one class of plasmids carried the $p c k A$ structural gene (Østerås et al., 1995). Strains carrying the second class of complementing plasmids, such as pTH69 (Fig. 1) showed increased $\mathrm{NAD}^{+}$-dependent malic enzyme activity and thus were putatively identified as carrying the $d m e$ gene.

As dme mutants induce root nodules which fail to fix $\mathrm{N}_{2}$ (Driscoll \& Finan, 1993), we tested pTH69 for complementation of this symbiotic phenotype. Plants inoculated with RmG454 and RmG456 transconjugants bearing pTH69 showed acetylene reduction values $66-81 \%$ of the wild-type values, whereas the $d m e$ mutant controls, RmG454 and RmG456, showed values of only $1 \cdot 2-1 \cdot 3 \%$, approximately equal to the activity determined for uninoculated root systems. Thus pTH69 restores $\mathrm{N}_{2}$-fixing ability to $d m e$ mutants.

\section{Genetic characterization of the dme gene}

The $3.1 \mathrm{~kb}$ HindIII and $8.5 \mathrm{~kb}$ EcoRI fragments of pTH69 (Fig. 1) were sub-cloned in both orientations into pRK7813. The resulting plasmids (pTH109, pTH111, pTH113 and pTH114, see Table 1) complemented the growth of $d m e$ pckA pod-1 strains (RmG443 or $\mathrm{RmG450)}$ on succinate indicating that the dme gene was present. A derivative of pTH111, in which the $0.4 \mathrm{~kb}$ sequence between the HindIII and EcoRI sites had been deleted, retained the ability to complement $\mathrm{RmG} 450$, indicating that this region was not required for expression of dme (Fig. 1). Plasmids pTH138 and pTH139 were constructed by sub-cloning the $3 \cdot 1 \mathrm{~kb}$ HindIII restriction fragment in both orientations into vector pUC119.

Growth of E. coli EJ1321 (dme tme pck) on succinate was complemented by plasmids pTH109, pTH113 and pTH139, but not by plasmids pTH111, pTH114 and pTH138, carrying the same fragments in the opposite orientation. Moreover, high levels of malic enzyme activity were detected in extracts from $E$. coli EJ1321(pTH139), but not in extracts from EJ1321(pTH138) cells (data not shown). Together, the
R. meliloti and E. coli data indicate that complementation in E. coli EJ1321 is due to dme transcription from the vector lac promoter, that $d m e$ transcription is from left to right with respect to Fig. 1 , and that the $R$. meliloti dme gene promoter is non-functional in E. coli.

Three derivatives carrying $\operatorname{Tn} 5$ insertions in the $3.1 \mathrm{~kb}$ HindIII fragment of pTH113 (dme-4::Tn5, dme$5:: \operatorname{Tn} 5$, and dme-6::Tn5 see Fig. 1) failed to complement growth of $R$. meliloti RmG450 (dme pckA pod1) on succinate. The $d m e:: \operatorname{Tn} 5$ insertions were recombined into the $R$. meliloti genome and were then transduced into different $R$. meliloti strains. The transductants had identical phenotypes to strains carrying $d m e$ mutations (Driscoll \& Finan, 1993). Tn 5 insertions, such as $\Omega 5301:$ : $\operatorname{Tn} 5$, which mapped outside the dme gene region, did not affect malic enzyme activity, nor did they affect $\mathrm{N}_{2}$-fixation (data not shown).

To localize the $d m e$ gene on the $R$. meliloti chromosome we mapped the gentamycin and spectinomycin resistance markers of the Tn5-233 insertions $\Omega 5285$ (see Fig. 1) and $\Omega 5286$ which co-transduce at $100 \%$ and $30 \%$, respectively, with the $d m e$ gene (see Methods). Two groups of seven rifampicin-sensitive donor strains each carrying one of seven Tn5-mob insertions, the mobilizing plasmid, pGMI102, and $\Omega 5285:: \operatorname{Tn} 5-233$ or 25286::Tn5-233 were constructed. The Tn5-mob strains transfer large regions of the $R$. meliloti chromosome in a polar fashion as in the case of E. coli $\mathrm{Hfr}$ strains (Finan et al., 1988; Klein et al., 1992). These were then mated with the rifampicin-resistant recipient strain $\mathrm{Rm} 5000$ and recombinants were selected on LB medium containing rifampicin, gentamycin and spectinomycin. The highest frequencies of recombinants resulted from the $\Omega 637:: \operatorname{Tn} 5-m o b$ insertion (linked to $c y s-11$ ), followed by $\Omega 601:: \operatorname{Tn} 5-m o b$ (linked to leu-53) and lastly 2614: :Tn5-mob (linked to pyr-49). From the Tn5-mob position and direction of transfer (Klein et al., 1992), we conclude that the dme gene mapped to the $R$. melilot $i$ chromosome in the region between cys-11 and leu-53, but closer to cys-11 than leu-53.

\section{Regulation of dme gene expression in free-living cells}

Expression of $d m e$ was examined using transcriptional lac $Z$ gene fusions generated with the transposon Tn5B20 (Simon et al., 1989). Two pTH69: : Tn5-B20 derivatives, pTH226 and pTH241, which failed to complement RmG450 for growth on succinate were isolated. Both Tn5-B20 insertions were mapped by restriction analysis to within the $d m e$ gene (see Fig. 1) such that expression of $d m e$ would result in lac $Z$ expression and hence production of the $\beta$-galactosidase protein. The dme: $: \operatorname{Tn} 5-\mathrm{B} 20$ insertions were recombined into the $\mathrm{Lac}^{-}$R. meliloti strain RmG212 and as expected only low levels of $\mathrm{NAD}^{+}$-, but normal $\mathrm{NADP}^{+}$-dependent malic enzyme activities were detected in cell extracts from these recombinants.

Strains carrying the $d m e-7:: \operatorname{Tn} 5-\mathrm{B} 20$ insertion on the chromosome or plasmid (pTH226) showed less than a 
Table 2. Regulation of dme expression in $R$. meliloti under different growth conditions

Cells were grown as described (see Methods) in minimal media with either succinate or glucose as sole carbon source, or in LBmc. Data presented are means \pm standard error of triplicate measurements of each sample.

\begin{tabular}{|c|c|c|c|c|}
\hline \multirow[t]{2}{*}{ Strain" } & \multirow[t]{2}{*}{ Relevant characteristics } & \multicolumn{3}{|c|}{$\begin{array}{c}\beta \text {-Galactosidase specific activity } \\
\text { (Miller units) }\end{array}$} \\
\hline & & Succinate & Glucose & LBmc \\
\hline $\mathrm{RmG} 212$ & $\mathrm{Lac}^{-}$ & $9 \pm 4$ & $14 \pm 3$ & $9 \pm 1$ \\
\hline $\mathrm{RmH} 182$ & pTH69 dme-7: : Tn5-B20 & $861 \pm 4$ & $744 \pm 3$ & $1278 \pm 15$ \\
\hline $\mathrm{RmH} 239$ & $d m e-7:: \operatorname{Tn} 5-\mathrm{B} 20$ & $244 \pm 8$ & $230 \pm 3$ & $288 \pm 5$ \\
\hline $\mathrm{RmH} 239 \mathrm{O} / \mathrm{N}$ & $d m e-7:: \operatorname{Tn} 5-\mathrm{B} 20$ & $268 \pm 3$ & $125 \pm 2$ & $207 \pm 3$ \\
\hline $\mathrm{RmH} 239 \mathrm{O} / 2 \mathrm{~N}$ & $d m e-7:: \operatorname{Tn} 5-\mathrm{B} 20$ & $253 \pm 3$ & $144 \pm 3$ & $303 \pm 15$ \\
\hline
\end{tabular}

" O/N, overnight; $\mathrm{O} / 2 \mathrm{~N}$, over two nights.

\section{Table 3. Expression of the $d m e$ and tme genes in $R$. meliloti bacteroids}

Bacteroids were isolated from plants harvested $27 \mathrm{~d}$ after inoculation with the bacterial strains. Free-living cells were grown in LBmc with tetracycline $\left(5 \mathrm{mg} \mathrm{m}^{-1}\right)$ to select for plasmids (except for $\mathrm{RmG} 212$ ). Data presented are means \pm standard error of triplicate measurements.

\begin{tabular}{|c|c|c|c|c|}
\hline \multirow[t]{2}{*}{ Strain } & \multirow[t]{2}{*}{ Relevant characteristics } & \multicolumn{3}{|c|}{$\begin{array}{l}\beta \text {-Galactosidase specific activity } \\
{\left[\mathrm{nmol} \mathrm{min}^{-1}(\text { mg protein })^{-1}\right]}\end{array}$} \\
\hline & & $\begin{array}{l}\text { Free-living } \\
\text { cells }\end{array}$ & Bacteroids & $\begin{array}{l}\text { Percentage of } \\
\text { free-living } \\
\text { cells }^{*}\end{array}$ \\
\hline $\mathrm{RmG} 212$ & $\mathrm{Lac}^{-}$ & $8 \pm 1$ & $6 \pm 1$ & - \\
\hline $\mathrm{RmH} 240$ & $\mathrm{Lac}^{-}(\mathrm{pTH} 69)$ & $6 \overline{ \pm} 2$ & $\overline{\mathrm{ND}}$ & - \\
\hline $\mathrm{RmH} 182$ & pTH69 dme-7: : Tn5-B20 & $3498 \pm 190$ & $1334 \pm 102$ & 87 \\
\hline $\mathrm{RmH} 201$ & pRmT100 tme-7: : Tn5-B20 & $2465 \pm 135$ & $215 \pm 7$ & 20 \\
\hline
\end{tabular}

ND, Not determined; -, not applicable.

"For comparison with free-living cells values for bacteroids were multiplied by a factor of $2 \cdot 27$ (to 3028 for RmH182 and to 488 for RmH201) (see Results).

threefold difference in $\beta$-galactosidase activity following growth in minimal medium with glucose or succinate as carbon source or in complex LBmc medium $[10 \mathrm{~g}$ tryptone (Difco), 5 g yeast extract, $5 \mathrm{~g} \mathrm{NaCl}, 4 \mathrm{ml} 1 \mathrm{M}$ $\mathrm{NaOH}, 11 \mathrm{H}_{2} \mathrm{O} ; \mathrm{MgSO}_{4}$ and $\mathrm{CaCl}_{2}$ each added after autoclaving to final concentrations of $2.5 \mathrm{mM}$ ) (Table 2). Cells bearing the plasmid fusion (pTH226) showed 3.4 to 4 -fold greater activity than cells with chromosomal dme-7:: Tn5-B20 insertions. This is presumably due to the higher copy number of the plasmid-carried fusion. In summary, the level of $d m e$ gene expression, like that of the tme gene (Driscoll \& Finan, 1996), showed very little response to differences in growth conditions.

As pckA expression in $R$. meliloti was induced in stationary phase (Østerås et al., 1995), we measured $\beta$ galactosidase activity in $\mathrm{RmH} 239$ (dme-7:: Tn5-B20) cells after prolonged incubation (Table 2). No increase in activity was detected in cells grown in LBmc or minimal medium with succinate as sole carbon source, but reduced $\beta$-galactosidase activity was observed in cells grown with glucose as sole carbon source. The significance of the latter result is unclear. Our results showing little genetic regulation of $d m e$ expression are consistent with previous data in which similar levels of malic enzyme activities were detected in cells grown in different media (Driscoll \& Finan, 1993).

\section{Expression of the dme and tme genes in bacteroids}

The regulation of $d m e$ and tme in nodules was examined by measuring $\beta$-galactosidase activities in bacteroids carrying plasmid-borne tme and dme lacZ gene fusions (Table 3). We used plasmid-borne fusions as dme mutants induced nodules which did not fix nitrogen. To compare free-living and bacteroid $\beta$-galactosidase activities, it was necessary to correct for plasmid loss which occurs during bacteroid formation. The proportion of bacteroids retaining a typical pLAFR1 

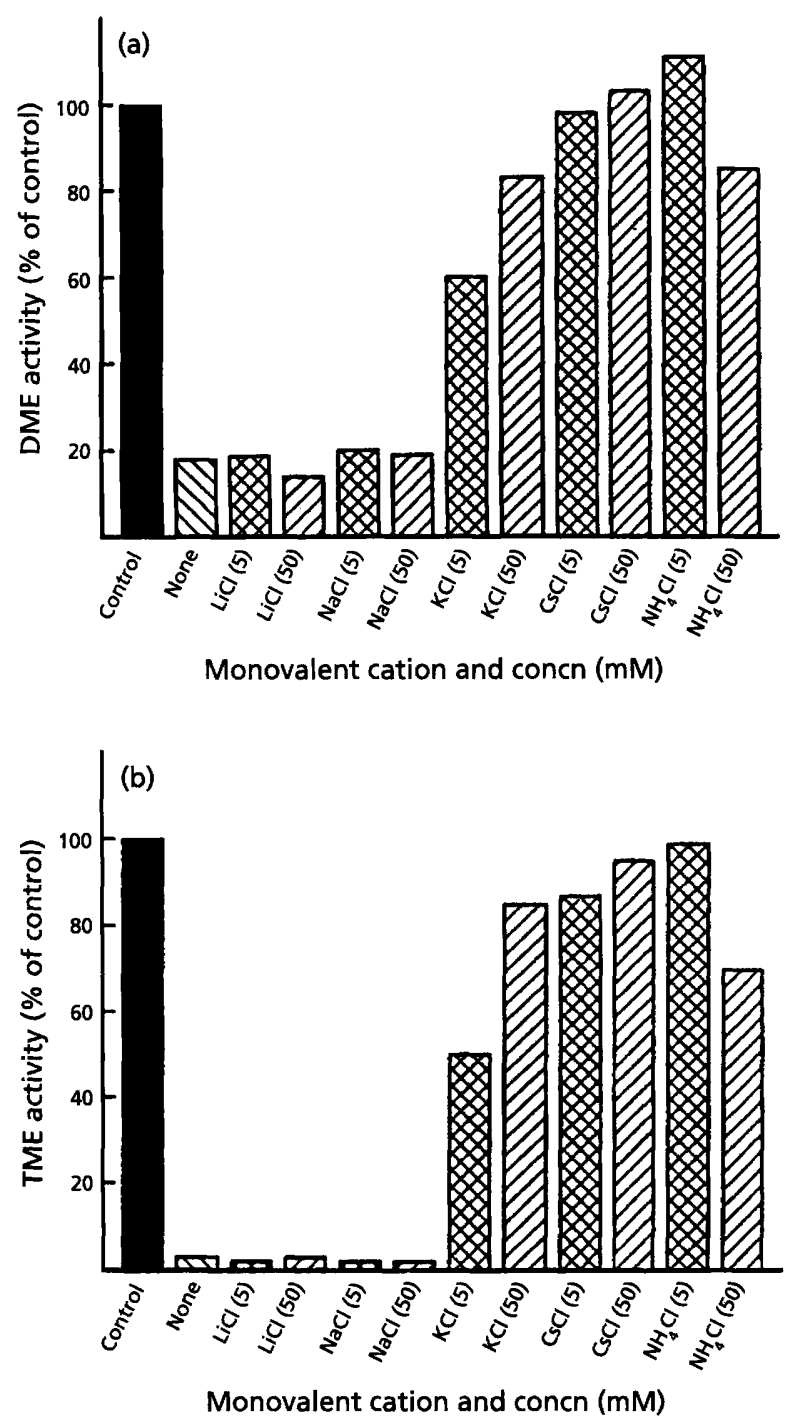

Fig. 2. Effect of monovalent cations on (a) DME and (b) TME activities. The enzymes were equilibrated in assay mixtures containing $3 \mathrm{mM} \mathrm{MnCl}_{2}, 30 \mathrm{mM}$ sodium L-malate and the indicated concentrations of monovalent cation chloride salts. Controls were assayed in the standard solution plus $50 \mathrm{mM} \mathrm{KCl}$. Activities were initiated by the addition of coenzyme $(2.5 \mathrm{mM}$ $\mathrm{NAD}^{+}$for DME, $0.25 \mathrm{mM} \mathrm{NADP}{ }^{+}$for TME). The results represent percentage of the control values $\left[372 \pm 18 \mathrm{nmol} \mathrm{min}^{-1}(\mathrm{mg}\right.$ protein $)^{-1}$ for DME and $63.7 \pm 8.1 \mathrm{nmol} \mathrm{min}^{-1}(\mathrm{mg} \text { protein) })^{-1}$ for $\mathrm{TME}$, and were determined from the means of triplicate measurements of each sample.

plasmid ( $\mathrm{pRmT100}$ ) was determined to be $44 \%$. Consequently, the bacteroid $\beta$-galactosidase specific activity multiplied by a factor of $2 \cdot 27$, was calculated to be $87 \%$ of the free-living cell value for the $d m e$-lac $Z$ fusion, and $20 \%$ for the tme-lac $Z$ fusion. Only negligible $\beta$-galactosidase activity was detected in extracts of the $\mathrm{Lac}^{-}$ control strains RmG212 and RmG240 (Table 3). The low level of tme gene expression detected in bacteroids is in agreement with our previous finding that most, if not all of the $\mathrm{NADP}^{+}$-dependent malic enzyme activity detected in bacteroid extracts is due to utilization of
NADP $^{+}$by DME (Driscoll \& Finan, 1996). In summary, we conclude that the $d m e$ gene is expressed in bacteroids whereas the tme gene is repressed.

\section{Partial purification of the malic enzymes}

As the malic enzymes were difficult to purify while maintaining enzyme activity, we sought to determine some basic biochemical properties of the enzymes from partially purified preparations. A similar approach was used to study Bradyrhizobium japonicum malic enzymes (Copeland et al., 1989). To study the properties of DME, we wished to isolate a DME preparation free of both TME and MDH.

The R. meliloti DME protein was overexpressed in $E$. coli EJ1321(pTH139) and separated from E. coli $\mathrm{MDH}$ by DEAE-cellulose chromatography (Driscoll et al., 1993). In the concentrated DME preparation a $15: 1$ ratio of DME activity with the coenzymes $\mathrm{NAD}^{+}$ $(0.25 \mathrm{mM})$ and $\mathrm{NADP}^{+}(0.25 \mathrm{mM})$ was observed. A prominent band of molecular mass $74000 \mathrm{Da}$, which appeared to be the over-expressed DME, was observed on SDS-polyacrylamide gels loaded with EJ1321(pTH139) extract. This band was not observed in lanes loaded with extracts of $E$. coli EJ1321(pTH138) or EJ1321 (data not shown). E. coli DME and TME are reported to have molecular masses of $57500 \mathrm{Da}$ and $67000 \mathrm{Da}$, respectively (Spina et al., 1968; Yamaguchi et al., 1973).

Preparations of TME which were free of DME were isolated by DEAE-cellulose chromatography of proteins extracted from the $R$. meliloti dme mutant strains RmG492 and RmG494 (Driscoll \& Finan, 1993; Driscoll et al., 1993). TME had a strict coenzyme specificity for $\mathrm{NADP}^{+}$as no NAD ${ }^{+}$-dependent activity was detected in the TME preparations.

\section{Characterization of the malic enzymes}

The optimal $\mathrm{pH}$ for both DME and TME was $\mathrm{pH} 7 \cdot 8$. As bacterial malic enzymes are known to be stimulated by monovalent cations, we measured DME and TME activities with each of five different monovalent cation chloride salts (Fig. 2). At $30 \mathrm{mM}$ potassium L-malate, the addition of $50 \mathrm{mM}$ monovalent cation salts appeared to cause a general, albeit slight, decrease in DME and TME activities indicating that both enzymes were nearly maximally stimulated by the potassium added with the potassium L-malate. Thirty millimolar sodium L-malate was therefore used in assay mixtures to measure enzyme activities in the presence of various monovalent cations. Under these conditions, trace amounts of $\mathrm{KCl}(20 \mu \mathrm{M}$ with DME, and $50 \mu \mathrm{M}$ with TME) were added with the enzyme preparations. The omission of additional monovalent cation reduced DME activity to $18 \%$ and TME activity to $3 \%$ of the control values (Fig. 2). Both enzymes were stimulated by $\mathrm{NH}_{4}^{+}, \mathrm{K}^{+}$and $\mathrm{Cs}^{+}$, and neither was stimulated by $\mathrm{Li}^{+}$. These results paralleled findings reported for other bacterial malic enzymes (Brown \& Cook, 1985; Chang et al., 1993; Lamed \& Zeikus, 1981; Garrido-Pertierra et al., 1983; Kobayashi 

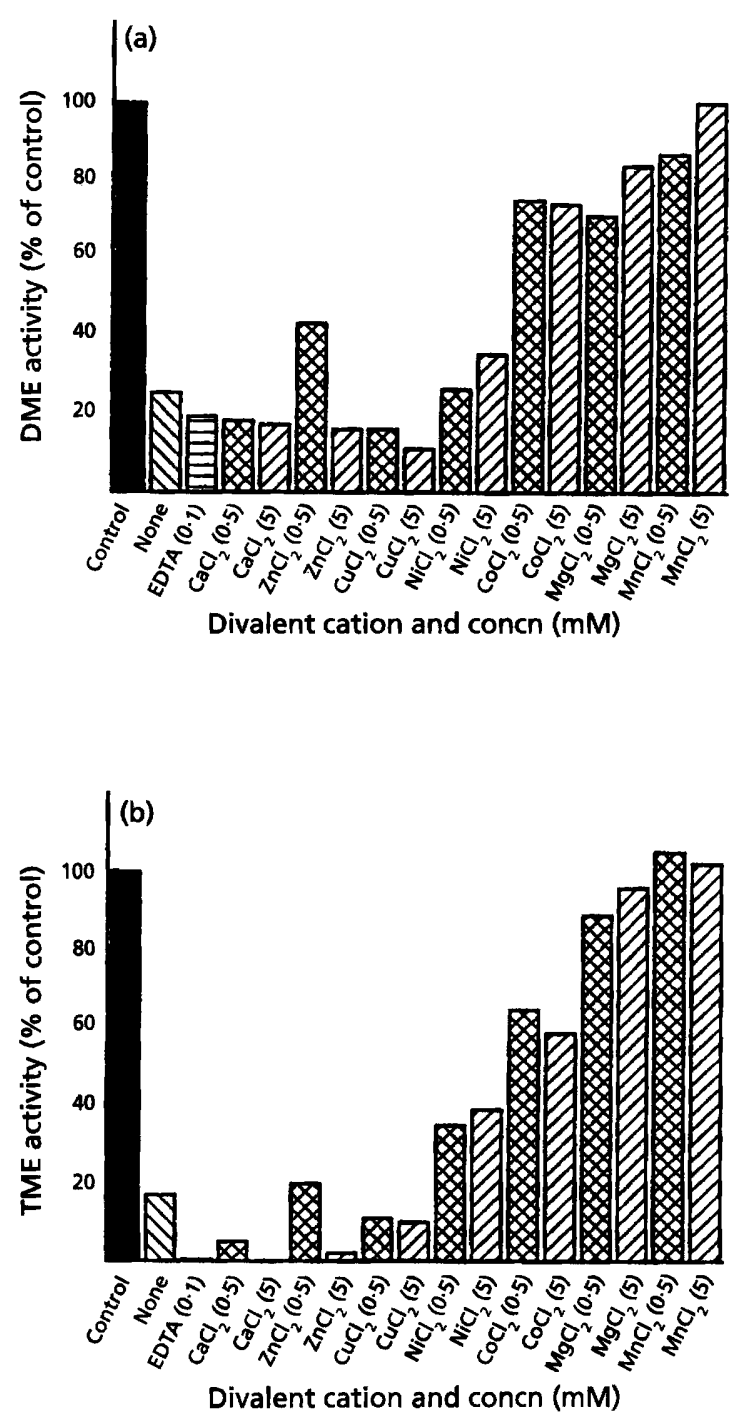

Fig. 3. Effect of divalent cations on (a) DME and (b) TME activities. The enzyme was equilibrated in assay mixtures containing $30 \mathrm{mM}$ potassium L-malate, $50 \mathrm{mM} \mathrm{KCl}$ and the indicated concentrations of divalent cation salts. Controls were assayed in the standard solution plus $3 \mathrm{mM} \mathrm{MnCl}{ }_{2}$. Activities were initiated by addition of coenzyme $\left(2.5 \mathrm{mM} \mathrm{NAD^{+ }}\right.$ for $D M E$, $0.25 \mathrm{mM} \mathrm{NADP}^{+}$for TME). The results represent percentage of the control values $\left[382 \pm 31 \mathrm{nmol} \mathrm{m^{-1 }}\left(\mathrm{mg}\right.\right.$ protein) ${ }^{-1}$ for DME and $78.5 \pm 9.3 \mathrm{nmol} \mathrm{min}^{-1}(\mathrm{mg} \text { protein })^{-1}$ for TME], and were determined from the means of triplicate measurements of each sample.

et al., 1989). Our results were not in agreement with those of Copeland et al. (1989), who showed that, while both malic enzymes isolated from $B$. japonicum bacteroids were stimulated by $\mathrm{NH}_{4}^{+}$, only the $\mathrm{NAD}^{+}$dependent malic enzyme was also stimulated by $\mathrm{K}^{+}$.

While only bacterial malic enzymes have been reported to be stimulated by monovalent cations, divalent cations are required by plant, animal and bacterial malic enzymes. The effects of seven different divalent cation chloride salts on DME and TME activities were examined (Fig. 3). In these experiments trace amounts of
Table 4. Summary of kinetic analyses of TME and DME in R. meliloti

Apparent $K_{\mathrm{m}}$ and $V_{\max }$ values were calculated by linear regression analysis of the data plotted as $[\mathrm{S}] v^{-1}$ vs [S]. All enzyme assays were done in triplicate. The concentrations of malate, $\mathrm{NAD}^{+}$and $\mathrm{NADP}^{+}$used were $0.2-60 \mathrm{mM}$, $0.0125-5 \mathrm{mM}$ and $1 \cdot 25-500 \mu \mathrm{M}$, respectively.

\begin{tabular}{|c|c|c|c|}
\hline Enzyme & $\begin{array}{c}\text { Varied } \\
\text { compound }\end{array}$ & $\begin{array}{l}\text { Apparent } \\
K_{\mathrm{m}}(\mathrm{mM})\end{array}$ & $\underset{[\text { nmol min }}{V_{\max }}$ \\
\hline DME & Malate & $8 \cdot 6$ & 545 \\
\hline DME & $\mathrm{NAD}^{+}$ & $0 \cdot 142$ & 477 \\
\hline TME & Malate & $4 \cdot 7$ & 78 \\
\hline TME & $\mathrm{NADP}^{+}$ & 0.041 & 85 \\
\hline
\end{tabular}

$\mathrm{MgCl}_{2}$ in the enzyme preparation were present in each reaction $(2 \mu \mathrm{M}$ with $\mathrm{DME}$ and $5 \mu \mathrm{M}$ with TME). In the absence of additional divalent cations, DME and TME activities were reduced to $25 \%$ and $17 \%$, respectively, of control values determined in the presence of $3 \mathrm{mM} \mathrm{MnCl}{ }_{2}$. The addition of $0.1 \mathrm{mM} \mathrm{EDTA}$ to these reaction mixtures reduced TME activity to less than $1 \%$ of the control and DME to $19 \%$ of the control. Addition of $1 \mathrm{mM}$ EDTA did not affect DME and TME activities when $3 \mathrm{mM} \mathrm{MnCl}$ was also added to the assays (not shown). DME and TME activities were each highly stimulated by $\mathrm{Co}^{2+}, \mathrm{Mg}^{2+}$ and $\mathrm{Mn}^{2+}$, whereas both activities were slightly inhibited by $\mathrm{Cu}^{2+}, \mathrm{Ca}^{2+}$ and high concentrations of $\mathrm{Zn}^{2+}$. The similar responses of both malic enzymes to the different divalent cations is consistent with reports that malic enzymes in general appear to be stimulated by $\mathrm{Mn}^{2+}, \mathrm{Mg}^{2+}$ and $\mathrm{Co}^{2+}$, but not by $\mathrm{Ca}^{2+}$ and $\mathrm{Cu}^{2+}$ (Lamed \& Zeikus, 1981; GarridoPertierra et al., 1983; Bartolucci et al., 1987; Kobayashi et al., 1989; Drincovich et al., 1991).

We reasoned that the determination of the basic kinetic properties of DME and TME would aid in the elucidation of the distinct roles of the two enzymes in metabolism (Table 4). Thus the apparent $K_{\mathrm{m}}$ of DME for malate $(8.6 \mathrm{mM})$ was found to be approximately twice that of TME ( $4.7 \mathrm{mM})$, while the apparent $K_{\mathrm{m}}$ of DME for $\operatorname{NAD}^{+}(142 \mu \mathrm{M})$ was threefold greater than the apparent $K_{\mathrm{m}}$ of TME for $\mathrm{NADP}^{+}(41 \mu \mathrm{M})$.

We hypothesized that if DME and TME activities showed different patterns of regulation in response to metabolic effectors, the distinct roles of these enzymes in cellular metabolism could be more readily determined. The compounds tested for allosteric regulation of DME and TME activities were: acetyl-CoA (1, 10 and $100 \mu \mathrm{M}), 0.25 \mathrm{mM}$ NADH, $0.25 \mathrm{mM}$ NADPH, $1 \mathrm{mM}$ aspartate, $1 \mathrm{mM} \mathrm{CoA}, 50 \mathrm{mM} \mathrm{NaHCO}, 1 \mathrm{mM}$ pyridoxal $5^{\prime}$-phosphate, $1 \mathrm{mM}$ AMP, $1 \mathrm{mM}$ ADP and $1 \mathrm{mM}$ ATP (data not shown). Of these compounds, acetylCoA produced the most dramatic effect; $100 \mu \mathrm{M}$ acetylCoA reduced DME activity by $68 \%$. Although NADH 


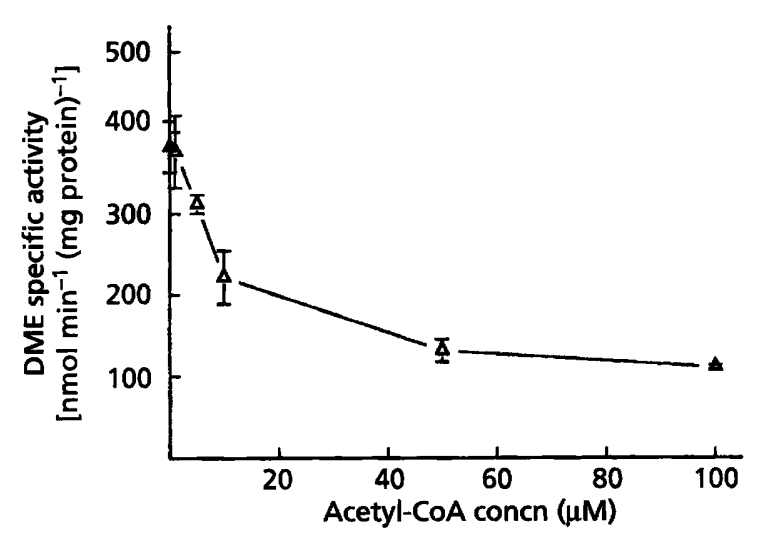

Fig. 4. Effect of varied acetyl-COA concentrations on DME activity. DME activity was initiated by the addition of enzyme $(0.014 \mathrm{mg}$ total protein) to the complete malic enzyme assay mixture containing the indicated concentration of acetyl-CoA. DME specific activity was determined by the rate of reduction of $\mathrm{NAD}^{+}$. Error bars represent the standard error of the mean of triplicate measurements.

also appeared to slightly inhibit DME, the rest of the compounds tested were found to have no significant effects. None of the compounds tested appeared to greatly affect TME activity, with the possible exception of $\mathrm{NaCO}_{3}(50 \mathrm{mM})$, which reduced TME activity by $27 \%$. Although acetyl-CoA clearly inhibited DME, even $100 \mu \mathrm{M}$ acetyl-CoA had no affect on TME activity.

\section{Inhibition of DME activity by acetyl-CoA}

Inhibition of DME activity was analysed by initiating complete malic enzyme assays, containing $1,5,10,50$ or $100 \mu \mathrm{M}$ acetyl-CoA, with a fixed amount of enzyme (Fig. 4). Acetyl-CoA concentrations of 5 and $10 \mu \mathrm{M}$ reduced DME activity by $18 \%$ and $42 \%$, respectively. Maximal inhibition was observed at concentrations between $50 \mu \mathrm{M}$ and $100 \mu \mathrm{M}$. In additional experiments, we measured DME activity at varying malate concentrations in assay mixtures containing 0,10 or $50 \mu \mathrm{M}$ acetyl-CoA. Analysis of the resulting data using double reciprocal plots did not allow us to determine the type of inhibition, suggesting that the response of DME to acetyl-CoA is complex.

\section{DISCUSSION}

R. meliloti has two malic enzymes: DME, which shows maximal activity with $\mathrm{NAD}^{+}$as co-factor and TME, which employs only $\mathrm{NADP}^{+}$as co-factor. We have previously reported the cloning and regulation of the tme gene (Driscoll \& Finan, 1996). Here, we have cloned and localized the $d m e$ gene to a fragment of $3 \cdot 1 \mathrm{~kb}$ and used this fragment to overproduce the DME protein in E. coli. To aid in defining the metabolic roles of the two malic enzymes, we characterized partially purified preparations of the overproduced DME and partially purified TME preparations isolated from $R$. meliloti dme mutants. The enzymes had many similarities, including $\mathrm{pH}$ optima, sensitivity to various metabolic effectors and activities in the presence of various monovalent and divalent cations. The $K_{\mathrm{m}}$ of DME for malate $(8.6 \mathrm{mM})$ was slightly higher than that of TME (4.7 mM).

The most striking difference between the two proteins lay in their differential sensitivity to acetyl-CoA, which strongly inhibited DME activity without having an observable effect on TME. Results from kinetic experiments did not allow us to define the type of acetyl-CoA inhibition of DME; however, inhibition was clearly evident at acetyl-CoA concentrations as low as $10 \mu \mathrm{M}$. We and others (McKay et al., 1988; Kouchi et al., 1988; Copeland et al., 1989) have hypothesized that malic enzyme, with PDH, is important for the conversion of malate to acetyl-CoA in $\mathrm{N}_{2}$-fixing bacteroids. A pathway for the conversion of $\mathrm{C}_{4}$-dicarboxylates to acetyl-CoA is necessary if the TCA cycle is to operate in cells, such as bacteroids, which are supplied with $\mathrm{C}_{4}$-dicarboxylic acids as sole energy source. Thus the acetyl-CoA inhibition of DME, together with the Fix ${ }^{-}$phenotype of the R. meliloti dme mutants (Driscoll \& Finan, 1993), supports the hypothesis that acetyl-CoA is the endproduct of a metabolic pathway to which DME belongs.

Although the $R$. meliloti DME appears to have a catabolic role in bacteroids, its role, and the role of TME, in free-living cells is less clear. TME may be primarily an anapleurotic enzyme, however, Sanwal (1970) hypothesized that, in E. coli, it may also be involved in the biosynthesis of amino acids and/or lipids from TCA cycle intermediates. Our data suggest that in $R$. meliloti TME would be active in circumstances where acetyl-CoA and presumably TCA cycle intermediates which are precursors in many biosynthetic pathways accumulate. As $\mathrm{NADP}^{+}$-dependent malic enzymes have been partially purified from $B$. japonicum bacteroids (Copeland et al., 1989; Kimura \& Tajima, 1989 ), this activity may be important in these cells. $B$. japonicum bacteroids store poly- $\beta$-hydroxybutyrate, while $R$. meliloti bacteroids do not (McRae et al., 1989). In B. japonicum bacteroids, therefore, NADP ${ }^{+}$dependent malic enzyme activity may be involved in a pathway (with PDH) that converts malate to acetylCoA, which can then be converted to poly- $\beta$-hydroxybutyrate. The NADPH generated via this pathway may also be important for biosynthetic processes within these cells.

The location of $d m e$ on the chromosome is far from the previously mapped position of tme (Driscoll \& Finan, 1996). Many symbiosis-specific genes map to the nod-nif megaplasmid in $R$. meliloti. While dme is essential for symbiotic nitrogen fixation (Driscoll \& Finan, 1993), it does not appear to be symbiosis-specific; it is expressed in free-living cells, and in addition $\mathrm{NAD}^{+}$-dependent malic enzymes are found in many other organisms.

We observed little variation in $d m e$ expression in freeliving cells cultured under different growth conditions (Table 2). These data parallel the levels of DME enzyme activity detected in crude extracts of cells grown under 
similar conditions (Driscoll \& Finan, 1993). Our results do not show the same degree of regulation as observed for $E$. coli where $\mathrm{NAD}^{+}$-dependent malic enzyme activity is repressed by glucose and induced by malate (Murai et al., 1971).

Our results strongly suggest that tme is repressed in bacteroids (Table 3 ). This supports previous data indicating that most, if not all, of the TME activity detected in bacteroids was due to the utilization of $\mathrm{NADP}^{+}$by DME in vitro (Driscoll \& Finan, 1996). In contrast to tme, we estimated that the level of $d m e$ expression in bacteroids is similar to that found in freeliving cells (Table 3 ). In view of these results, it will be interesting to identify and compare the tme and $d m e$ promoters, and further to determine whether the same dme promoter is used in free-living cells and bacteroids.

\section{ACKNOWLEDGEMENTS}

We would like to thank Magne Østerås, Asif Khattak and Jason Marsh for technical assistance; and Elizabeth Weretilnyk, Peter Summers, Suman Mukhopadhyay and Herb Schellhorn for technical advice and use of equipment. T.M.F. acknowledges funding from the Natural Sciences and Engineering Research Council of Canada. We would also like to thank Ralf Voegele, Trevor Charles and Michael Mitsch for critical reading of the manuscript.

\section{REFERENCES}

Arwas, R., McKay, I. A., Rowney, F. R. P., Dilworth, M. J. \& Glenn, A. R. (1985). Properties of organic acid utilization mutants of Rhizobium leguminosarum strain 300. J Gen Microbiol 131, 2059-2066.

Bartolucci, S., Rella, R., Guagliardi, A., Raia, C. A., Gambacorta, A., De Rosa, M. \& Rossi, M. (1987). Malic enzyme from archaebacterium Sulfolobus solfataricus: purification, structure and kinetic properties. $J$ Biol Chem 262, 7725-7731.

Bolton, E., Higgisson, B., Harrington, A. \& O'Gara, F. (1986). Dicarboxylic acid transport in Rhizobium meliloti: isolation of mutants and cloning of dicarboxylic acid transport genes. Arch Microbiol 144, 142-146.

Brown, D. A. \& Cook, R. A. (1985). Regulatory effects of potassium and inorganic anions on the NADP-specific malic enzyme of Escherichia coli. Can J Biochem Cell Biol 63, 128-136.

Chang, G.-G., Satterlee, J. \& Hsu, R. Y. (1993). Essential sulfhydryl group of malic enzyme from Escherichia coli. J Protein Chem 12, 7-10.

Charles, T. C. \& Finan, T. M. (1990). Genetic map of Rhizobium meliloti megaplasmid pRmeSU47b. J Bacteriol 172, 2469-2476.

Copeland, L., Quinnell, R. G. \& Day, D. A. (1989). Malic enzyme activity in bacteroids from soybean nodules. J Gen Microbiol 135, 2005-2011.

Drincovich, M. F., Iglesias, A. A. \& Andreo, C. S. (1991). Interaction of divalent metal cations with the $\mathrm{NADP}^{+}$-malic enzyme from maize leaves. Physiol Plant 81, 462-466.

Driscoll, B. T. \& Finan, T. M. (1993). NAD ${ }^{+}$-depenent malic enzyme of $R$ hizobium meliloti is required for symbiotic nitrogen fixation. Mol Microbiol 7, 865-873.
Driscoll, B. T. \& Finan, T. M. (1996). NADP $^{+}$malic enzyme of Rbizobium meliloti. J Bacteriol 178, 2224-2231.

Driscoll, B. T., Østerås, M. \& Finan, T. M. (1993). Succinate metabolism in Rhizobium meliloti. In New Horizons in Nitrogen Fixation, pp. 517-522. Edited by R. Palacios, J. Mora \& W. Newton. Boston: Kluwer.

Engelke, T. H., Jagadish, M. N. \& Puhler, A. (1987). Biochemical and genetical analysis of Rhizobium meliloti mutants defective in $\mathrm{C}_{4}$-dicarboxylate transport. J Gen Microbiol 133, 3019-3029.

Englard, S. \& Siegal, L. (1969). Mitochondrial L-malate dehydrogenase of beef heart. Methods Enzymol 13, 99-100.

Finan, T. M., Wood, J. M. \& Jordan, D. C. (1983). Symbiotic properties of $\mathrm{C}_{4}$-dicarboxylate acid transport mutants of Rhizobium leguminosarum. J Bacteriol 154, 1403-1413.

Finan, T. M., Oresnik, I. \& Bottacin, A. (1988). Mutants of Rhizobium meliloti defective in succinate metabolism. J Bacteriol 170, 3396-3403.

Friedman, A. M., Long, S. R., Brown, S. E., Buikema, W. J. \& Ausubel, F. M. (1982). Construction of a broad host range cosmid cloning vector and its use in the genetic analysis of Rhizobium mutants. Gene 18, 289-296.

Garrido-Pertierra, A., Martinez Marcos, C., Martin Fernandez, M. \& Ruiz-Amil, M. (1983). Properties and function of malate enzyme from Pseudomonas putida. Biochimie 65, 629-635.

Hansen, E. J. \& Juni, E. (1975). Isolation of mutants of Escherichia coli lacking NAD- and NADP-linked malic enzyme activities. Biochem Biophys Res Commun 65, 559-566.

Jones, J. D. J. \& Gutterson, N. (1987). An efficient mobilizable cosmid vector, $p R K 7813$, and its use in a rapid method for marker exchange in Pseudomonas fluorescens strain HV37a. Gene 61, 299-306.

Kimura, I. \& Tajima, S. (1989). Presence and characteristics of NADP-malic enzyme in soybean nodules. Soil Sci Plant Nutr 35, 271-279.

Klein, S., Lohman, K., Clover, R., Walker, G. C. \& Signer, E. R. (1992). A directional, high frequency chromosomal localization system for genetic mapping in Rhizobium meliloti. J Bacteriol 174, 324-326.

Kobayashi, K., Doi, S., Negoro, S., Urabe, I. \& Okada, H. (1989). Structure and properties of malic enzyme from Bacillus stearothermophilus. J Biol Chem 264, 3200-3205.

Kouchi, H., Fukai, K., Katagiri, H., Minamisawa, K. \& Tajima, S. (1988). Isolation and enzymological characterization of infected and uninfected cell protoplasts from root nodules of Glycine max. Pbysiol Plant 73, 327-334.

Lamed, R. \& Zeikus, J. G. (1981). Thermostable, ammoniumactivated malic enzyme of Clostridium thermocellum. Biochim Biophys Acta 660, 251-255.

McKay, I. A., Dilworth, M. J. \& Glenn, A. R. (1988). $C_{4}$-dicarboxylate metabolism in free-living and bacteroid forms of Rbizobium leguminosarum MNF3841. J Gen Microbiol 134, 1433-1440.

McRae, D. G., Miller, R. W. \& Berndt, W. B. (1989). Viability of alfafa nodule bacteroids isolated by density gradient centrifugation. Symbiosis 7, 67-80.

Miller, J. H. (1972). Experiments in Molecular Genetics. Cold Spring Harbor, NY: Cold Spring Harbor Laboratory.

Murai, T., Tokushige, M., Nagai, J. \& Katsuki, H. (1971). Physiological functions of NAD- and NADP-linked malic enzymes in Escherichia coli. Biochem Biophys Res Commun 43, 875-881. 
Østerås, M., Driscoll, B. T. \& Finan, T. M. (1995). Molecular and expression analysis of the Rhizobium meliloti phosphoenolpyruvate carboxykinase ( $p c k A$ ) gene. J Bacteriol 177, 14521460.

Ronson, C. W., Lyttleton, P. \& Robertson, J. G. (1981). $\mathrm{C}_{4}-$ dicarboxylate transport mutants of Rhizobium trifolii form ineffective nodules on Trifolium repens. Proc Natl Acad Sci USA 78, 4284-4288.

Sambrook, J., Fritsch, E. F. \& Maniatis, T. (1989). Molecular Cloning: a Laboratory Manual, 2nd edn. Cold Spring Harbor, NY: Cold Spring Harbor Laboratory.

Sanwal, B. D. (1970). Allosteric controls of amphibolic pathways in bacteria. Bacteriol Rev 34, 20-39.

Simon, R., Quandt, J. \& Klipp, W. (1989). New derivatives of transposon Tn5 suitable for mobilizations of replicons, generation of operon fusions and induction of genes in Gramnegative bacteria. Gene 80, 161-169.

Spina, J., Jr, Bright, H. J. \& Rosenbloom, J. (1968). Purification and properties of L-malic enzyme from Escherichia coli. Biochemistry 9, 3794-3801.
Stoval, I. \& Cole, M. (1978). Organic acid metabolism by isolated Rhizobium japonicum bacteroids. Plant Physiol 61, 787-790.

Streeter, J. G. (1991). Transport and metabolism of carbon and nitrogen in legume nodules. Adv Bot Res 18, 129-187.

Van Slooten, J. C., Bhuvanasvari, T. V., Bardin, S. \& Stanley, J. (1992). Two $\mathrm{C}_{4}$-dicarboxylate transport systems in R bizobium sp. NGR234: rhizobial dicarboxylate transport is essential for nitrogen fixation in tropical legume symbiosis. Mol PlantMicrobe Interact 5, 179-186.

Yamaguchi, M., Tokushige, M. \& Katsuki, H. (1973). Studies on regulatory functions of malic enzymes. II. Purification and molecular properties of nicotinamide adenine dinucleotide-linked malic enzyme from Escherichia coli. J Biochem 73, 169-180.

Yarosh, O. K., Charles, T. C. \& Finan, T. M. (1989). Analysis of $C_{4}-$ dicarboxylic acid transport genes in Rhizobium meliloti. Mol Microbiol 3, 813-823.

Received 18 June 1996; revised 16 September 1996; accepted 19 September 1996. 